\title{
Ekstrakcija i ispitivanje stabilnosti polifenola komine masline u prirodnim eutektičkim otapalima
}

\author{
A. Mitar, D. Kučić Grgić i J. Prlić Kardum* \\ Fakultet kemijskog inženjerstva i tehnologije, Sveučilišta u Zagrebu \\ Marulićev trg 19, 10000 Zagreb
}

Ovo djelo je dano na korištenje pod Creative Commons Attribution 4.0 International License

https://doi.org/10.15255/KUI.2019.039

KUI-25/2019

Izvorni znanstveni rad

Prispjelo 28. kolovoza 2019.

Prihvaćeno 18. rujna 2019.

\begin{abstract}
Sažetak $30 \%$ vode optimalno otapalo za održavanje stabilnosti polifenola.

Ključne riječi

Ekstrakcija, polifenoli, prirodna niskotemperaturna eutektička otapala, stabilnost polifenola
\end{abstract}

Polifenolni spojevi, zaostali u komini koja je nusproizvod u proizvodnji maslinova ulja, antioksidansi su koji imaju pozitivan učinak na ljudsko zdravlje. Za izdvajanje polifenola sve češće se primjenjuju prirodna eutektička otapala koje karakterizira netoksičnost, biorazgradljivost, nezapaljivost te niska cijena. $U$ ovom radu upotrijebljeno je prirodno niskotemperaturno eutektičko otapalo (NADES) pripravljeno od triju komponenti: DL-jabučne kiseline, D-fruktoze i glicerola (MaFruGly) s različitim udjelima vode koji omogućavaju uspješnu ekstrakciju polifenola. Određena je optimalna metoda ekstrakcije, a nakon provedene ekstrakcije, ekstrakti su podvrgnuti mikrobiološkoj analizi te je praćena stabilnost izdvojenih polifenola. Istraživanje je pokazalo da su najuspješnije metode za ekstrakciju polifenola mikrovalno ultrazvučna te ekstrakcija ultrazvučnom sondom, a NADES s

\section{Uvod}

Bioaktivne spojeve kao što su sekundarni metaboliti te razni antioksidansi pronalazimo u biljkama koje ih u velikim količinama proizvode procesom fotosinteze. Ti prirodni antioksidansi poput polifenola imaju sposobnost sprječavanja mnogih bolesti, usporavaju starenje, imaju pozitivne učinke na degenerativne i kardiovaskularne bolesti te smanjuju oštećenja na stanicama uzrokovana djelovanjem slobodnih radikala i oksidativnim stresom. ${ }^{1,2}$ Mnogi tradicionalno upotrijebljeni prirodni antioksidansi iz čajeva, vina, voća i povrća te ljekovitog bilja već se rabe kao aditivi ili kao nutrijenti. ${ }^{3,4}$ Maslinova komina i lišće te otpadna voda vrijedni su izvori antioksidativnih polifenola koji nastaju u velikim količinama u procesu proizvodnje maslinova ulja. $S$ druge strane, ti isti nusproizvodi imaju negativan učinak na okoliš zbog potencijalno fitotoksičnog djelovanja. lako se otpad nastao nakon proizvodnje maslinova ulja može rabiti kao energent za proizvodnju toplinske energije spaljivanjem komine, kao gnojivo, herbicid ili pesticid, kao hrana za životinje, u proizvodnji različitih proizvoda (alkohola, biosurfaktanata, biopolimera, aktivnog ugljena) te za ekstrakciju organskih spojeva (pektina, fenola itd), još uvijek je velik problem pri zbrinjavanju. ${ }^{5,6}$

U posljednje vrijeme sve veća upotreba bioaktivnih spojeva u farmaceutskoj, prehrambenoj i kemijskoj industriji iziskuje pronalazak odgovarajućih metoda i otapala za ekstrakciju tih spojeva iz biljnih materijala. ${ }^{7}$ Izvrsna fizikalno-kemijska svojstava (neznatna hlapljivost, podesiva viskoznost, široko područje polarnosti itd.) te sposobnosti otapanja različitih komponenti učinila je prirodna niskotemperaturna eutektička otapala (engl. Natural Deep Eutectic Solvents, NADES) pogodnim otapalima za ekstrakciju bioaktivnih komponenti iz prirodnih izvora. ${ }^{8,9}$ NADES-i

*Autor za dopisivanje: prof. dr. sc. Jasna Prlić Kardum e-pošta: jprlic@fkit.hr su kapljevine pripremljene iz primarnih metabolita (šećeri, organske kiseline, aminokiseline itd.) povezanih jakim međumolekulskim interakcijama, najviše vodikovim vezama, biorazgradljivi su, netoksični, nezapaljivi a pripremaju se jednostavno iz jeftinih komponenti. ${ }^{9-11}$ Spomenuta svojstva i prednosti tih zelenih otapala u odnosu na konvencionalna otapala daju mogućnost primjene NADES-a u različitim područjima. Tako se npr. upotrebljavaju u enzimatskim reakcijama i za povećanje stabilnosti enzima, ${ }^{12,13}$ u elektrokemiji ${ }^{14,15}$ te za ekstrakciju prirodnih spojeva. .,10,11,16 $^{2}$

Upotrebom neškodljivih i prirodnih otapala u procesu ekstrakcije moguće je izravno aplicirati dobiveni ekstrakt te je važno odrediti njihovu stabilnost u NADES-u. NADES zbog svojih jedinstvenih fizikalno-kemijskih svojstava (viskoznost i pH) ima velik potencijal za usporavanje degradacije bioaktivnih komponenti dobivenih ekstrakcijom. Veliku ulogu u povećanju topljivosti bioaktivnih spojeva imaju šećeri u NADES-ima koji stvaraju dodatne vodikove veze, pa je i stabilnost samih spojeva u ekstraktima bolja.

Cilj ovog rada bio je provesti ekstrakciju polifenola iz komine masline primjenom NADES-a pripremljenog od DL-jabučne kiseline, D-fruktoze i glicerola uz dodatak vode. Nadalje, određena je optimalna metoda ekstrakcije, ispitana je stabilnost dobivenog ekstrakta pri različitim uvjetima svjetla, temperature i udjela vode te je provedena mikrobiološka analiza ekstrakta odnosno ispitala se prisutnost bakterija i gljiva u navedenim uzorcima.

\section{Eksperimentalni dio}

\subsection{Priprema komine masline}

Komina masline (porijeklom iz Istre) dobivena je kao vlažna kaša te je do početka istraživanja skladištena u zamrzi- 
vaču $\left(-18^{\circ} \mathrm{C}\right)$ kako bi se spriječila degradacija polifenola. Prije samog procesa ekstrakcije komina se odmrznula i sušila u laboratorijskom sušioniku pri $60{ }^{\circ} \mathrm{C}$. Procesom sušenja uklonjena je zaostala voda u komini te je osušena komina usitnjena. Usitnjavanje je provedeno na električnom mlinu u trajanju od 1 do 2 min. Takav uzorak je zatim prosijan na situ promjera očica $800 \mu \mathrm{m}$ kako bi se uklonili ostatci koštica. Specifična površina čestica i veličina pora komine izmjerene su na uređaju ASAP 2000 (Micromeritics). Raspodjela veličina čestica određena je metodom laserske difrakcije primjenom uređaja za lasersku difrakciju SALD-3101 (Shimadzu). Raspodjele su izmjerene tri puta te je rezultat izražen kao srednja vrijednost, odnosno srednji promjer čestica komine. Pomoću uređaja Accupyc 1330 (Micromeritics) određena je gustoća maslinove komine.

\subsection{Proces ekstrakcije}

Za proces ekstrakcije polifenola iz komine masline primjenom različitih metoda upotrijebljen je NADES MaFruGly (DL-jabučna kiselina-D-fruktoza-glicerol) s 30 mas. \% vode. Za pripremu NADES-a upotrijebljene su kemikalije navedene u tablici 1. NADES je pripremljen miješanjem navedenih komponenti u molarnom odnosu $1: 1: 1$ u rotacijskom vakuumskom isparivaču IKA RV 10, Basic u razdoblju od $2 \mathrm{~h}$ pri temperaturi $60{ }^{\circ} \mathrm{C}$. Pripremljenom NADES-u određena su fizikalno-kemijska svojstva prikazana u tablici 2. Ispitan je i utjecaj udjela vode (20 - 100 mas. \%) na efikasnost ekstrakcije, a pomoću FTIR analize ispitan je utjecaj dodatka vode na strukturu NADES-a.

Tablica 1 - Kemikalije upotrijebljene za pripremu NADES-a Table 1 - Chemicals used for NADES preparation

\begin{tabular}{c|c|c|c|c}
\hline $\begin{array}{c}\text { Kemikalija } \\
\text { Chemicals }\end{array}$ & $M / \mathrm{g} \mathrm{mol}^{-1}$ & $\rho / \mathrm{g} \mathrm{cm}^{-3}$ & $\begin{array}{c}\text { Čistoća } / \% \\
\text { Purity/\% }\end{array}$ & $\begin{array}{c}\text { Proizvođač } \\
\text { Producer }\end{array}$ \\
\hline $\begin{array}{c}\text { DL-jabučna } \\
\text { kiselina }\end{array}$ & 194,09 & 1,609 & 99,0 & $\begin{array}{c}\text { Acros } \\
\text { Organics }\end{array}$ \\
\hline D-fruktoza & 180,16 & 1,690 & 99,0 & Lachner \\
\hline glicerol & 92,10 & 1,260 & 99,0 & BDH Prolabo \\
\hline
\end{tabular}

Ekstrakcija je provedena na magnetskoj miješalici RotaMix 609 mm, Tehtnica, u mikrovalno-ultrazvučnom ekstraktoru Lab Kis;W-ER-01, ultrazvučnoj kupelji i s ultrazvučnom sondom Sonopuls HD 320, Bandelin (frekvencije 20 kHz). Za svaku metodu određeno je vrijeme potrebno za uspostavljanje ravnotežnih uvjeta te je ispitan utjecaj dodatka vode $(20-100 \%)$ u NADES na ekstrakciju polifenola.

\subsection{Određivanje ukupne koncentracije polifenola}

Za određivanje ukupne koncentracije fenola primijenjena je standardna metoda Folin-Ciocalteau (FC) s nekim modifikacijama. ${ }^{17} \mathrm{U}$ odmjerne tikvice od $10 \mathrm{ml}$ pipetirano je $400 \mu \mathrm{l}$ Folin-Ciocalteu reagensa i $60 \mu \mathrm{l}$ filtriranog ekstrakta i tako su ostavljene tijekom 8 min na tamnom mjestu, zatim je u tikvice dodano $4 \mathrm{ml}$ (7 mas. \%) otopine natrijeva karbonata i do oznake dodana destilirana voda. Pripremljene otopine postupno poprimaju karakteristično plavo obojenje. Tikvice s pripremljenim otopinama omotane su aluminijskom folijom i termostatirane sat vremena pri temperaturi $40{ }^{\circ} \mathrm{C}$. Mjerenjem apsorbancije uzorka na uređaju pri maksimalnoj valnoj duljini od $756 \mathrm{~nm}$ kvantitativno je određena koncentracija ukupnih fenola te je izražena preko ekvivalentne koncentracije galne kiseline.

\subsection{Mikrobiološka analiza ekstrakta}

Određivanje broja stanica bakterija i gljiva (kvasaca i plijesni) u ekstraktima odredilo se na dva načina:

(a) $1 \mathrm{ml}$ ekstrakta otpipetiran je u sterilne Petrijeve zdjelice, zaliven hranjivim, odnosno sladnim agarom za uzgoj bakterija i gljiva, i homogeniziran 7 - 10 puta u obliku broja osam. Petrijeve zdjelice su zatim inkubirane u termostatu pri temperaturama $37^{\circ} \mathrm{C}$ i $28{ }^{\circ} \mathrm{C}$ u vremenu $24-48 \mathrm{~h}$ za bakterije odnosno 3 - 5 dana za gljive. Broj mikroorganizama određen je brojanjem izraslih kolonija te izražen kao CFU (engl. Colony Forming Units) [st $\left.\mathrm{ml}^{-1}\right]$.

(b) Na prethodno izlivenu hranjivu podlogu (hranjivi agar/ sladni agar) u Petrijevoj zdjelici otpipetirano je $0,1 \mathrm{ml}$ priređenog ekstrakta te se ekstrakt ravnomjerno homogenizirao po hranjivoj podlozi štapićem po Drigalskom. Petrijeve zdjelice su zatim inkubirane u termostatu pri temperaturama od $37{ }^{\circ} \mathrm{C}$ i $28{ }^{\circ} \mathrm{C}$ u vremenu $24-48 \mathrm{~h}$ za bakterije odnosno 3 - 5 dana za gljive. Broj mikroorganizama određen je brojanjem izraslih kolonija te izražen kao CFU [st ml ${ }^{-1}$. Mikrobiološka ispitivanja provedena su u sterilnim uvjetima rada.

\subsection{Stabilnost polifenola}

Ispitana je stabilnost polifenola u ekstraktu pri različitim uvjetima skladištenja. Koncentracija je praćena kroz razdoblje od dva mjeseca, prvi mjesec svakih tjedan dana a zatim nakon dva tjedna. Ispitan je utjecaj svjetlosti (dnevno svjetlo, UV-svjetlo i mrak) i temperature (sobna temperatura $\left(25^{\circ} \mathrm{C}\right)$, zamrzivač $\left(-18{ }^{\circ} \mathrm{C}\right)$ i hladnjak $\left(4^{\circ} \mathrm{C}\right)$ ). Također je ispitana i stabilnost polifenola u NADES-u s različitima udjelima vode (30 mas. \% i 50 mas. \%). U svrhu usporedbe NADES-a s konvencionalnim otapalima stabilnost polifenola ispitana je u etanolu i vodi. Tijekom istraživanja praćena je koncentracija polifenola u svim uzorcima primjenom navedene Folin-Ciocalteau metode.

Tablica 2 - Fizikalno-kemijska svojstva upotrijebljenog NADES-a pri $25^{\circ} \mathrm{C}$

Table 2 - Physicochemical properties of NADES at $25^{\circ} \mathrm{C}$

\begin{tabular}{c|c|c|c|c|c|c|c|c}
\hline DES & $w_{\mathrm{H}_{2} \mathrm{O}} / \%$ & $\rho / \mathrm{g} \mathrm{cm}^{-3}$ & $\eta / \mathrm{Pa} \mathrm{s}$ & $n_{\mathrm{D}}$ & $\mathrm{pH}$ & $\kappa / \mathrm{mS} \mathrm{cm}^{-1}$ & $\sigma / \mathrm{mN} \mathrm{m}^{-1}$ & $E_{\mathrm{NR}} / \mathrm{kcal} \mathrm{mol}^{-1}$ \\
\hline MaFruGly & 30 & 1,2950 & 0,0361 & 1,4426 & 0,92 & 0,366 & 57,73 & 49,73 \\
\hline
\end{tabular}


Tablica 3 - Svojstva komine masline

Table 3 - Olive pomace properties

\begin{tabular}{|c|c|c|c|c|}
\hline $\begin{array}{l}\text { Temperatura sušenja } /{ }^{\circ} \mathrm{C} \\
\text { Drying temoerature } /{ }^{\circ} \mathrm{C}\end{array}$ & $\begin{array}{c}\text { Specifična površina pora }(B E T) / \mathrm{m}^{2} \mathrm{~g}^{-1} \\
\text { BET surface area } / \mathrm{m}^{2} \mathrm{~g}^{-1}\end{array}$ & $\begin{array}{l}\text { Srednja veličina pora } / \mathrm{nm} \\
\text { Average pore size } / \mathrm{nm}\end{array}$ & $\begin{array}{l}\text { Srednja veličina čestica / } \mu \mathrm{m} \\
\text { Average partical size } / \mu \mathrm{m}\end{array}$ & $\rho / \mathrm{g} \mathrm{cm}^{-3}$ \\
\hline 60 & 4,74 & 11,86 & 93,04 & 1,298 \\
\hline
\end{tabular}

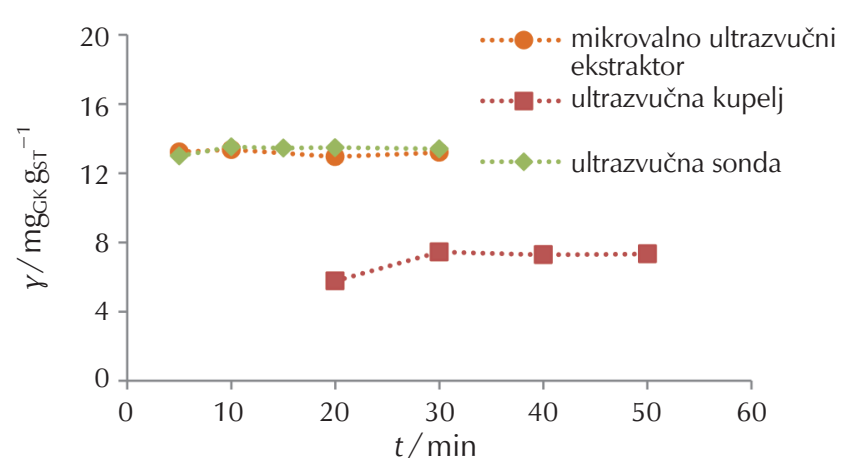

Slika 1 - Vrijeme potrebno za uspostavljanje ravnotežnih uvjeta za ekstrakciju primjenom mikrovalno ultrazvučnog ekstraktora, ultrazvučne kupelji i ultrazvučne sonde

Fig. 1 - Time required to establish equilibrium extraction conditions using a microwave ultrasonic extractor, ultrasonic bath, and ultrasonic probe

\section{Rezultati i rasprava}

Prije ekstrakcije komina je osušena pri $60{ }^{\circ} \mathrm{C}$ kako bi se uklonio višak vode. Pokazalo se da sušenje na višim temperaturama od $60{ }^{\circ} \mathrm{C}$ dovodi do skupljanja pora i smanjenja specifične površine komine. Posljedica toga je smanjenje kontaktne površine između komine i kapljevine, što dovodi do smanjenja djelotvornosti procesa ekstrakcije. Svojstva upotrijebljene komine prikazana su u tablici 3 . Kako bi se ekstrakcija provela pri optimalnim uvjetima, ispitane su različite metode provedbe ekstrakcije, određena optimalna vremena provedbe te dobivene koncentracije ekstrahiranih polifenola primjenom različitih metoda.

Vrijeme potrebno za postizanje ravnotežnih uvjeta u mikrovalno-ultrazvučnom ekstraktoru i s ultrazvučnom sondom iznosi 10 min, za magnetsku miješalicu 30 min, dok se primjenom ultrazvučne kupelji ravnotežni uvjeti postižu nakon 40 min djelovanja ultrazvuka (slike 1 i 2).

Kraće vrijeme ekstrakcije i bolji prinos dobiven je primjenom mikrovalno ultrazvučnog ekstraktora i ultrazvučne sonde (slike 1 i 3a). Jedan od razloga je povišenje temperature primjenom mikrovalnih i ultrazvučnih valova $\left(40{ }^{\circ} \mathrm{C}\right.$ do $60{ }^{\circ} \mathrm{C}$ ), a dodatno i njihov mehanizam djelovanja. Naime, djelovanje mikrovalnog zračenja i ultrazvučnih valova doprinosi boljem prijenosu tvari jer se pospješuje difuzija ključne komponente kroz staničnu stijenku. Pri mikrovalnom zračenju nastaje neionizirano elektromagnetsko zračenje koje uslijed kretanja iona i rotacije molekula te atomskih dipola zagrijava i otapalo i uzorak. Zbog zagrijavanja biljnih stanica isparava vezana vlaga, stvara se visok tlak na staničnoj stijenci, što rezultira bubrenjem biljne stanice. ${ }^{18}$ To u konačnici dovodi do pucanja stanične stijen-

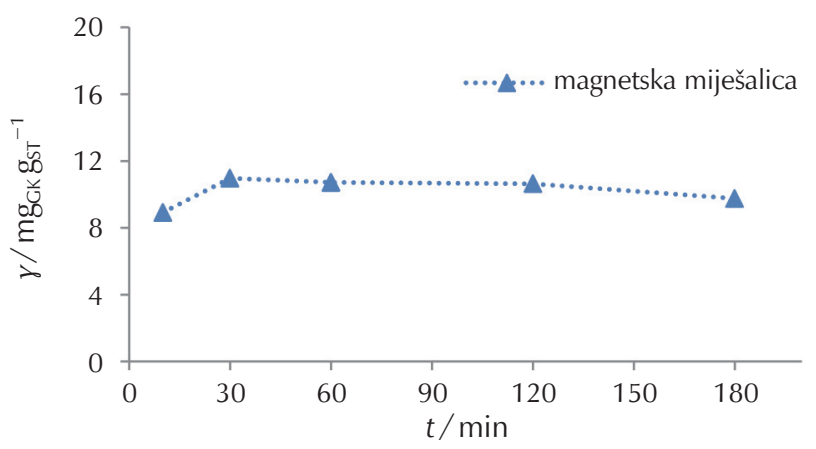

Slika 2 - Vrijeme potrebno za uspostavljanje ravnotežnih uvjeta za ekstrakciju primjenom magnetske miješalice

Fig. 2 - Time required to establish equilibrium extraction conditions using a magnetic stirrer

ke, što olakšava ekstrakciju polifenola iz stanice u otapalo, čime se povećava učinkovitost ekstrakcije. Do dodatnog utjecaja mikrovalno ultrazvučnog ekstraktora na povećanje koncentracije došlo je zbog zagrijavanja ekstrakcijske smjese budući da se celuloza (glavni sastojak biljne stanične stijenke) razgrađuje pri visokoj temperaturi koja se

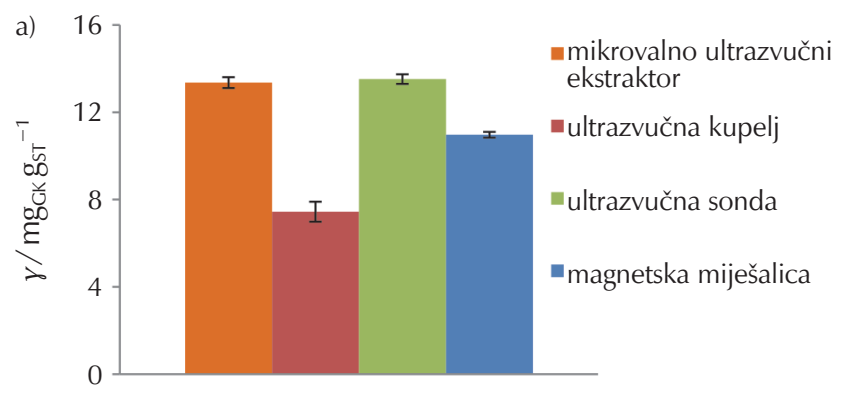

b)

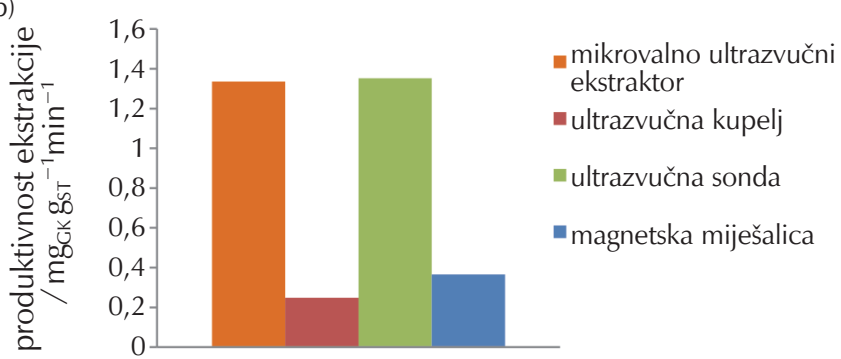

Slika 3 -a) Utjecaj različitih metoda ekstrakcije na koncentraciju polifenola; b) utjecaj različitih metoda ekstrakcije na produktivnost ekstrakcije

Fig. 3 - a) Influence of different extraction methods on polyphenols concentration; b) influence of different extraction methods on extraction productivity 


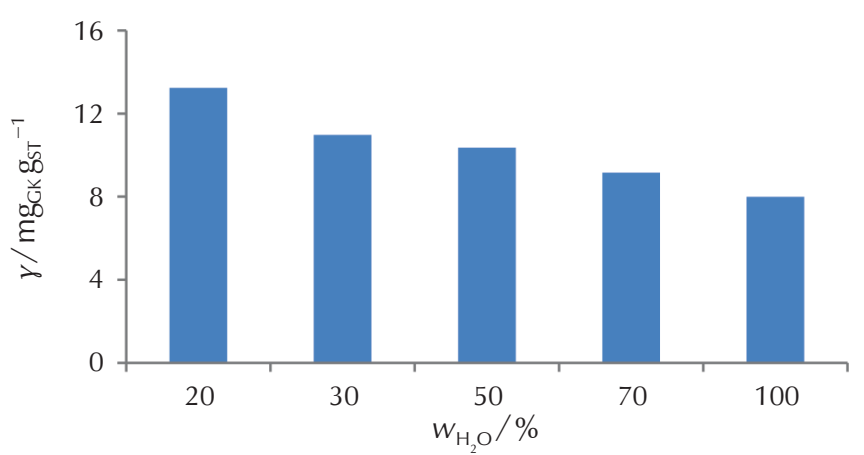

Slika 4 - Utjecaj udjela vode u NADES-u na ekstrakciju polifenola primjenom magnetskog miješala pri $25{ }^{\circ} \mathrm{C}(\sigma=0,28)$

Fig. 4 - Influence of water content in NADES on polyphenols extraction with magnetic stirrer at $25{ }^{\circ} \mathrm{C}(\sigma=0.28)$

postiže mikrovalnim zračenjem. Time se smanjuje njezina mehanička čvrstoća te se povećava kretanje otapala u unutrašnjost stanice. ${ }^{19}$

Proces ekstrakcije može se odvijati difuzijom kroz staničnu stijenku i/ili izdvajanjem sadržaja iz stanice čije su stanične stijenke popucale zbog utjecaja ultrazvuka, što dovodi do poboljšanja ekstrakcije. ${ }^{20}$ Naime, pri djelovanju ultrazvučnog zračenja pospješuje se kontakt između uzorka i otpala zbog stvaranja kavitacijskih mjehurića. Fenomen kavitacije, koji uzrokuje mikrorupture staničnog materijala, tj. stijenki, omogućuje prodiranje otapala u stanicu i na taj način dovodi do lakšeg prijenosa polifenola u otapalo. ${ }^{21}$ Za razliku od ultrazvučne sonde gdje se postiže visok intenzitet ultrazvuka koji dovodi do pojave kavitacije, kod ultrazvučne kupelji taj fenomen nije ostvaren u tolikoj mjeri budući da se ultrazvuk prenosi kroz vodenu kupelj, što smanjuje količinu dostavljene energije po volumenu uzorka. Ekstrakcija provedena magnetskim miješalom, unatoč povoljnim hidrodinamičkim uvjetima, također se pokazala manje učinkovitom. Razlog tome je mehanizam prijenosa polifenola iz krutine u NADES. Kod te metode ne dolazi do pucanja stanične stijenke i ostvaren je samo prijenos tvari kroz difuzijski granični sloj na granici faza. Dodatno, na slici 3b prikazana je produktivnost ekstrakcije koja uzima u obzir vrijeme potrebno za određeni prinos polifenola. Vidljivo je da je razlika u produktivnosti za mikrovalno ultrazvučni ekstraktor i ultrazvučnu sondu znatno veća od ostale dvije metode. Takav rezultat dodatno potvrđuje uspješnost spomenutih ekstrakcijskih metoda i intenzivniji mehanizam prijenosa tvari koji se ostvaruje djelovanjem ultrazvučnih i magnetskih valova.

Kako bi se ispitao utjecaj vode na ekstrakciju i kasnije na stabilnost polifenola u ekstraktu, provedena je ekstrakcija polifenola iz NADES-a s 20, 30, 50 i 70 \% vode te iz čiste vode. Koncentracija ekstrahiranih polifenola je veća što je manji udio vode u NADES-u (slika 4). Razlog tome je bolja topljivost polifenola u NADES-u. Naime, općenito se vjeruje da na učinkovitost ekstrakcije pojedinih komponenti može utjecati njihova polarnost, difuzivnost, topljivost te viskoznost i površinska napetost otapala. ${ }^{10,22}$ Osim navedenog, u tom slučaju važno je spomenuti i međumolekularne interakcije i sposobnost stvaranja vodikovih veza između NADES-a i polifenola. Kako bi se ostvarilo dobro

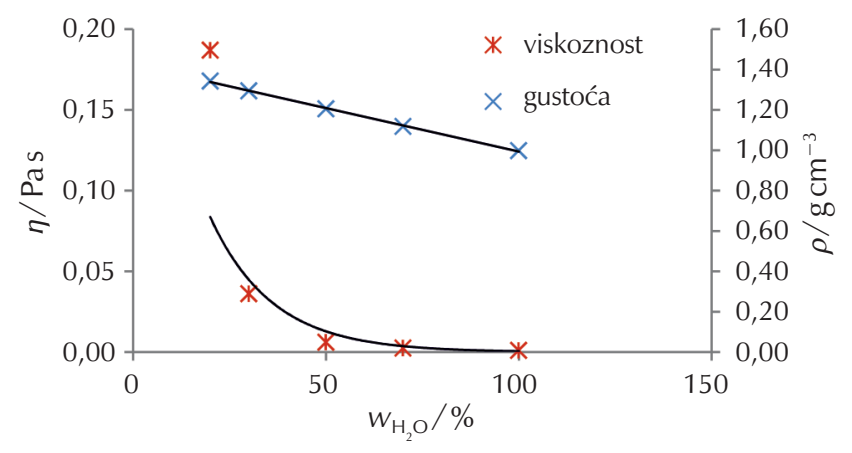

Slika 5 - Utjecaj udjela vode u NADES-u na gustoću i viskoznost pri $25{ }^{\circ} \mathrm{C}$

Fig. 5 - Influence of water content in NADES on density and viscosity at $25^{\circ} \mathrm{C}$

miješanje i visoka djelotvornost ekstrakcije, prilikom izbora otapala važno je uzeti u obzir fizikalna svojstva NADES-a (osobito viskoznost otapala). Iz grafa utjecaja udjela vode u NADES-u na gustoću i viskoznost (slika 5) jasno se može vidjeti da NADES s $20 \%$ vode ima izrazito visoku viskoznost i nešto veću gustoću, pa je zbog svega navedenog NADES s $30 \%$ vode optimalan za daljnju primjenu.

Ovisno o komponentama od kojih je pripravljen NADES te nastalim međumolekulskim vezama koje se stvaraju u kapljevini, dodatak vode može narušiti strukturu NADES-a. Stoga je primijenjena FTIR analiza kako bi se istražila struktura NADES-a pri različitim udjelima vode, slika 6. Iz prikazanih spektara vidljivo je da se povećanjem udjela vode smanjuje intenzitet apsorbancije veza u NADES-u, a povećava se intenzitet apsorbancije veza $\mathrm{O}-\mathrm{H}\left(1639 \mathrm{~cm}^{-1}\right)$ i $\mathrm{H}-\mathrm{O}-\mathrm{H}\left(3600-2700 \mathrm{~cm}^{-1}\right)$, karakterističnih za vodu. Također, vidljivo je da voda i NADES sa 70 \% vode nemaju pikove pri 1716 i $2940 \mathrm{~cm}^{-1}$, koji su karakteristični za NADES i vidljivi su s 20, 30 i 50 \% vode. Iz toga možemo zaključiti da je pri 70 \% vode došlo je do narušavanja strukture NADES-a.

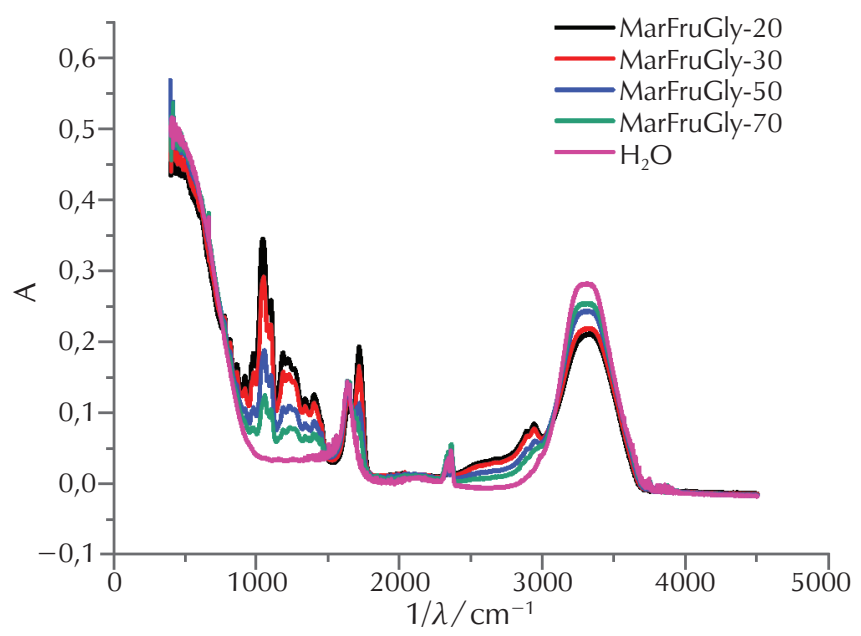

Slika 6 - FTIR spektri vode i NADES-a s različitim udjelima vode Fig. 6 - FTIR spectra of water and NADES with different water contents 
Zbog potencijalne primjene u kozmetici važno je ispitati mikrobiološku aktivnost dobivenih ekstrakata. Na slici 7 dan je prikaz ukupnog broja izraslih stanica bakterija i gljiva u uzorcima ekstrakta s različitim udjelima vode. Može se primijetiti da ni u jednom uzorku nisu izrasle bakterije, dok gljive, konkretno kvasci, jesu. pH-vrijednost navedenih eutektičkih otapala bila je niska, $\mathrm{pH}=1,1-1,7$, što pogoduje rastu gljiva, dok bakterijama ne pogoduje. Nadalje, navedeni ekstrakti sadržavali su visoku koncentraciju šećera, a poznato je da su gljive otpornije na visok osmotski tlak od bakterija. ${ }^{23}$ Nadalje, gljive mogu rasti na tvarima s vrlo malim udjelom vode, koji je općenito premalen za rast bakterija. Prisutnost vode u otapalima pogoduje rastu i razmnožavanju stanica kvasca te se njihov broj povećava s povećanjem udjela vode u NADES-u.

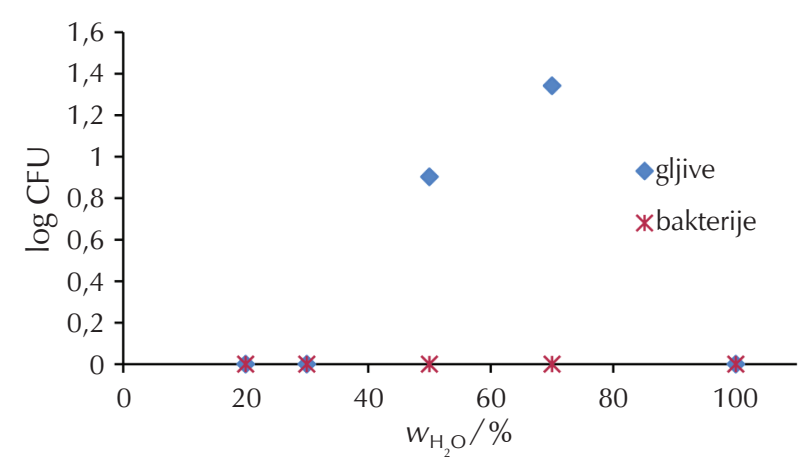

Slika 7 - Broj mikroorganizama u ekstraktima s različitim udjelima vode

Fig. 7 - Number of microorganisms in extracts with different water contents

Osim ostvarene učinkovitosti ekstrakcije, gdje su se različiti NADES-i pokazali kao bolji izbor za ekstrakciju polifenola od klasičnih otapala, ${ }^{16}$ važno je osigurati dobru i dugotrajnu stabilnost u NADES-u. Stabilnost dobivenih ekstrakata važna je za njihovu potencijalnu primjenu u kozmetici ili farmaceutici. Kako NADES-i nisu lakohlapljive kapljevine, izdvajanje polifenola zahtijeva složene i skupe postupke, kao što su dubinska filtracija ili ispiranje različitim otapali-

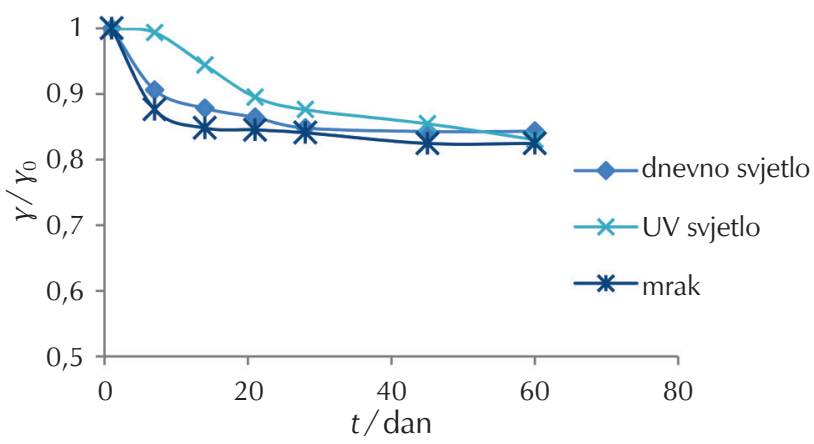

Slika 8 - Stabilnost polifenola u NADES-u MaFruGly-30 pri $25^{\circ} \mathrm{C}$ za različite uvjete svjetla

Fig. 8 - Stabilisation of polyphenols in NADES MaFruGly-30 at $25{ }^{\circ} \mathrm{C}$ for different light conditions ma. ${ }^{24}$ Praćenjem stabilnosti polifenola u različitim uvjetima kroz razdoblje od 60 dana ustanovljeno je da uvjeti svjetla nemaju značajan utjecaj na degradaciju polifenola (slika 8). Pri svim uvjetima svjetla (dnevno svjetlo, UV svjetlo i mrak) došlo je do slične degradacije polifenola, $16-18 \%$.

Za razliku od utjecaja svjetla, utjecaj temperature na skladištenje ekstrakta pokazao se nešto značajniji. Naime, praćenjem razdoblja od 60 dana ekstrakti čuvani u zamrzivaču na temperaturi od $-18{ }^{\circ} \mathrm{C}$ pokazali su najsporiju degradaciju polifenola (slika 9).

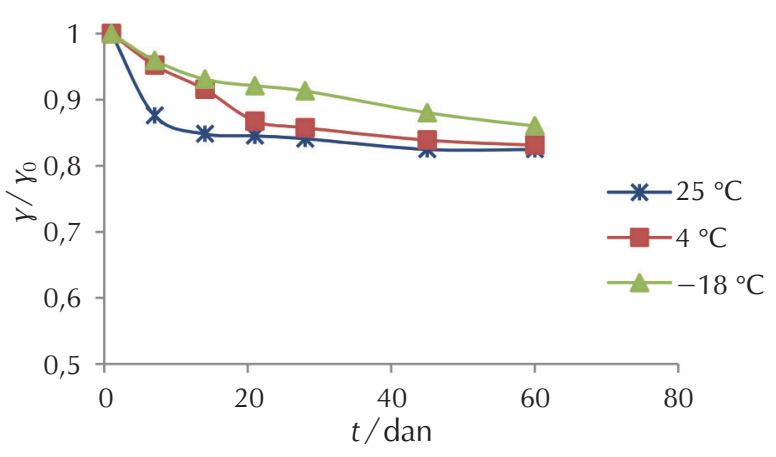

Slika 9 - Stabilnost polifenola u NADES-u MaFruGly-30 u mraku za različite temperature

Fig. 9 - Stability of polyphenols in NADES MaFruGly-30 in the dark for different temperatures

Radi usporedbe stabilnosti polifenola u različitim otapalima provedena je ekstrakcija polifenola s vodom, etanolom te je njihova stabilnost uspoređena sa stabilnošću polifenola u istraživanom NADES-u s 30 i 50 mas. \% vode. Na slici 10 vidljivo je da je tijekom 60 dana najviše polifenola degradiralo u etanolu, oko $48 \%$. Taj rezultat potvrđuje da su NADES-i pogodna otapala za ekstrakciju, ali i održavanje stabilnosti izdvojenih polifenola kroz dulje razdoblje. Udio vode (30 ili $50 \%$ ) ne igra značajnu ulogu u stabilnosti ekstrahiranih polifenola. U NADES-u s $30 \%$ vode nakon 60 dana degradiralo je $15 \%$ polifenola, dok je u NADES-u

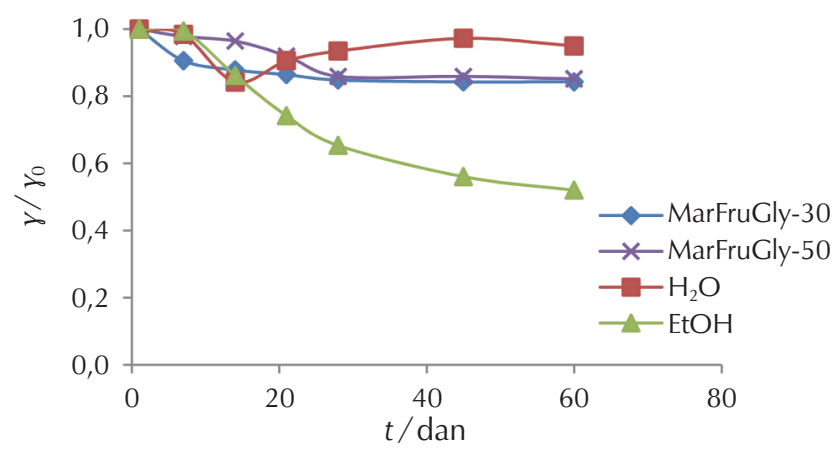

Slika 10 - Stabilnost polifenola u različitim otapalima pri $25^{\circ} \mathrm{C} \mathrm{u}$ uvjetima dnevnog svjetla

Fig. 10 - Stabilisation of polyphenols in various solvents at $25^{\circ} \mathrm{C}$ under daylight 
s $50 \%$ vode degradiralo $14 \%$ polifenola. Može se pretpostaviti da je visoka kiselost otapala te dodatak vode od 50 \% razlog zadovoljavajućeg održanja stabilnosti izdvojenih polifenola. Rezultati stabilnosti polifenola u vodi nisu reprezentativni jer su se tijekom praćenja stabilnosti razvile kulture gljiva i plijesni (slika 7).

Iz grafičkog prikaza utjecaja NADES-a, vode i etanola u mraku na stabilnost polifenola, prikazanog na slici 11, vidljivo je da je stabilizacija u etanolu poboljšana u uvjetima mraka jer je degradiralo manje polifenola, $36 \%$. U NADES-u uvjeti čuvanja (svijetlo ili mrak) nisu utjecali na stabilnost polifenola. To dodatno potvrđuje da je NADES otapalo pogodno za ekstrakciju polifenola iz komine masline, kojem se održava dobra stabilnost, bez obzira na uvjete čuvanja. Rezultati stabilnosti polifenola u vodi kao i kod uvjeta dnevnog svjetla ne mogu se uzeti u obzir jer su gljive izrasle i u uvjetima mraka.

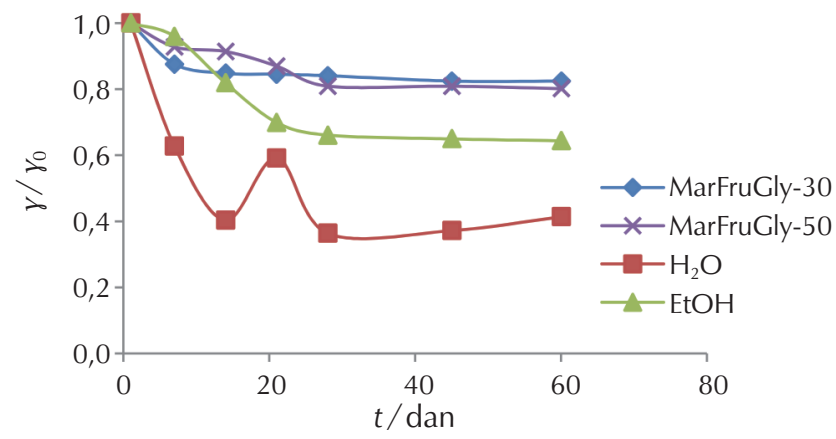

Slika 11 - Stabilnost polifenola u različitim otapalima pri $25^{\circ} \mathrm{C} \mathrm{u}$ uvjetima mraka

Fig. 11 - Stabilisation of polyphenols in various solvents at $25{ }^{\circ} \mathrm{C}$ in dark

\section{Zaključak}

$\mathrm{U}$ ovom radu ispitan je utjecaj različitih metoda ekstrakcije, određeno je optimalno vrijeme za pojedinu metodu te je ispitan utjecaj udjela vode u NADES-u na ekstrakciju polifenola iz komine masline, njihova fizikalna svojstva (viskoznost i gustoću) te na strukturu. Provedena je mikrobiološka analiza ekstrakta i praćena je stabilnost ekstrahiranih polifenolnih spojeva u NADES-u kroz razdoblje od 60 dana za različite uvjete svjetla i temperature te stabilnost polifenola u etanolu i vodi. Najbolje metode za ekstrakciju polifenola su mikrovalno ultrazvučna ekstrakcija i ekstrakcija ultrazvučnom sondom. NADES s $30 \%$ vode pokazao se kao optimalno otapalo za proces ekstrakcije jer ima pogodnu viskoznost i gustoću za proces ekstrakcije, pri tome nije narušena struktura NADES-a te je ekstrahirana veća koncentracija polifenola u odnosu na NADES-e s 50 i 70 \% vode. Zbog kiselih uvjeta u ekstraktu nisu se razvile ni bakterije ni gljive. NADES se pokazao kao pogodno otapalo za održavanje stabilnosti polifenola kroz dulje vrijeme. Najmanja degradacija polifenola postignuta je u NADES-ima (30 i 50 mas. \% vode) pri $-18{ }^{\circ} \mathrm{C}$. Etanol i voda pokazali su se kao lošija otapala u odnosu na NADES za održavanje stabilnosti polifenola. Sve navedeno dovodi do zaključka da postoji dobra mogućnost izravne primjene NADES-a nakon ekstrakcije u kozmetičkoj industriji.

\section{Popis kratica i simbola List of abbreviations and symbols}

\begin{tabular}{|c|c|}
\hline CFU & $\begin{array}{l}\text { - broj izraslih kolonija } \\
\text { - colony forming unit }\end{array}$ \\
\hline GK & $\begin{array}{l}\text { - galna kiselina } \\
\text { - galic acid }\end{array}$ \\
\hline NADES & $\begin{array}{l}\text { - prirodno niskotemperaturno eutektičko otapalo } \\
\text { - Natural Deep Eutectic Solvent }\end{array}$ \\
\hline NR & $\begin{array}{l}\text { - Nile Red metoda } \\
\text { - Nile Red method }\end{array}$ \\
\hline ST & $\begin{array}{l}\text { - suha tvar } \\
\text { - dry material }\end{array}$ \\
\hline$E$ & $\begin{array}{l}\text { - polarnost, } \mathrm{kcal} \mathrm{mol}^{-1} \\
\text { - polarity, kcal mol }\end{array}$ \\
\hline$n_{\mathrm{D}}$ & $\begin{array}{l}\text { - indeks loma } \\
\text { - refractive index }\end{array}$ \\
\hline w & $\begin{array}{l}\text { - maseni udio, } 100, \% \\
\text { - mass fraction, } 100, \%\end{array}$ \\
\hline$\eta$ & $\begin{array}{l}\text { - dinamička viskoznost, Pa s } \\
\text { - dynamic viscosity, Pa s }\end{array}$ \\
\hline$\gamma$ & $\begin{array}{l}\text { - masena koncentracija, } \mathrm{kg} \mathrm{m}^{-3} \\
\text { - mass concentration, } \mathrm{kg} \mathrm{m}^{-3}\end{array}$ \\
\hline$\kappa$ & $\begin{array}{l}\text { - električna provodnost, } \mathrm{mS} \mathrm{cm}^{-1} \\
\text { - conductivity, } \mathrm{mS} \mathrm{cm}^{-1}\end{array}$ \\
\hline$\rho$ & $\begin{array}{l}\text { - gustoća, } \mathrm{g} \mathrm{cm}^{-3} \\
\text { - density, } \mathrm{g} \mathrm{cm}^{-3}\end{array}$ \\
\hline$\sigma$ & $\begin{array}{l}\text { - površinska napetost, } \mathrm{mN} \mathrm{m}^{-1} \\
\text { - surface tension, } \mathrm{mN} \mathrm{m}^{-1}\end{array}$ \\
\hline
\end{tabular}




\section{Literatura \\ References}

1. M. Murkovic, Phenolic compounds, u Lu. Trugo and P. M. Finglas (ur.), Encyclopedia of Food Sciences and Nutrition. Vol. 7, Elsevier Science Ltd., 2003., 4507-4514, doi: https:// doi.org/10.1016/B0-12-227055-X/00914-7.

2. M. Saxena, J. Saxena, A. Pradhan, Flavonoids and phenolic acids as antioxidants in plants and human health, Int. J. Pharm. Sci. Rev. Res. 16 (2012) 130-134, doi: https://doi. org/10.5897/JMPR11.1404.

3. K. B. Pandey, S. I. Rizvi, Plant polyphenols as dietary antioxidants in human health and disease, Oxid. Med. Cell. Longev. 2 (5) (2009) 270-278, https://doi.org/10.4161/ oxim.2.5.9498

4. V. Lobo, A. Patil, A. Phatak, N. Chandra, Free radicals, antioxidants and functional foods: impact on human health, Pharmacogn. Rev. 4 (2010) 118-126, doi: https://doi. org/10.4103/0973-7847.70902.

5. O. Alketan, Potential of using olive pomace as a source of renewable energy for electricity generation in the Kingdom of Jordan, J. Renew. Sustain. Ener. 4 (6) (2012) 1-8, doi: https:// doi.org/10.1063/1.4769205.

6. D. V. Čepo, P. Albahari, M. Z. Končić, K. Radić, S. Jurmanović, M. Jug, Solvent extraction and chromatographic determination of polyphenols in olive pomace, Food Health Dis. 6 (2017) 7-14.

7. S. Sasidharan, Y. Chen, D. Saravanan, K. M. Sundram, L. Y. Latha, Extraction, isolation and characterization of bioactive compounds from plants' extracts, Afr. J. Tradit. Complement. Altern. Med. 8 (1) (2011) 1-10, doi: https://doi. org/110.10.4314/ajtcam.v8i1.60483.

8. Y. Dai, R. Verpoorte, Y. H. Choi, Natural deep eutectic solvents providing enhanced stability of natural colorants from safflower (Carthamus tinctorius), Food Chem. 159 (2014) 116121, doi: https://doi.org/10.1016/j.foodchem.2014.02.155.

9. S. Bajkacz, J. Adamek, Development of a Method Based on Natural Deep Eutectic Solvents for Extraction of Flavonoids from Food Samples, Food Anal. Method. 11 (5) (2018) 1330-1344, doi: https://doi.org/10.1007/s12161-0171118-5.

10. Y. Dai, G. J. Witkamp, R. Verpoorte, Y. H. Choi, Natural deep eutectic solvents as new extraction media for phenolic metabolites in safflower, Anal. Chem. 85 (13) (2013) 62726278, doi: https://doi.org/10.1021/ac400432p.

11. A. García, E. Rodríguez-Juan, G. Rodríguez-Gutiérrez, J. J. Rios, J. Fernández Bolaños, Extraction of phenolic compounds from virgin olive oil by deep eutectic solvents (DESs). Food. Chem. 197 (15) (2016) 554-561, doi: https://doi. org/10.1016/j.foodchem.2015.10.131.
12. J. T. Gorke, F. Srienc, R. J. Kazlauskas, Hydrolase-catalyzed biotransformations in deep eutectic solvents, Chem. Comm. 10 (2008) 1235-1237, doi: https://doi.org/10.1039/ B716317G.

13. J. L. Kaar, A. M. Jesionowski, J. A. Berberich, R. Moulton, A. J. Russell, Impact of ionic liquid physical properties on lipase activity and stability, J. Am. Chem. Soc. 125 (2003) 41254131, doi: https://doi.org/10.1021/ja028557x.

14. C. Brett, Deep Eutectic Solvents and Applications in Electrochemical Sensing, Curr. Opin. Electrochem. 10 (2018) 143148, doi: https://doi.org/10.1016/j.coelec.2018.05.016.

15. Q. Xu, T. S. Zhao, L. Wei, C. Zhang, X. L. Zhou, Electrochemical characteristics and transport properties of $\mathrm{Fe}(\mathrm{II}) / \mathrm{Fe}(\mathrm{III})$ redox couple in a non-aqueous reline deep eutectic solvent, Electrochim. Acta. 154 (2015) 462-467, doi: https://doi. org/10.1016/j.electacta.2014.12.061.

16. M. C. Bubalo, N. Ćurko, M. Tomašević, K. K. Ganić, I. R.Redovniković, Green extraction of grape skin phenolics by using deep eutectic solvents, Food Chem. 200 (2016) 159 166, doi: https://doi.org/10.1016/j.foodchem.2016.01.040.

17. C. Capannesi, I. Palchetti, M. Mascini, A. Parenti, Electrochemical sensor and biosensor for polyphenols detection in olive oils, Food Chem. 71 (2000) 553-562, doi: https://doi. org/10.1016/S0308-8146(00)00211-9.

18. M. V. Shah M. C. Rohit, Novel techniques for isolation and extraction of phytoconstituents from herbal plants, Am. J. Phytomed. Clin. Ther. 1 (2013) 338-350,

19. P. Tatkem, Y. Jaiswal, An Overview of Microwave Assisted Extraction and its Applications in Herbal Drug, Research, Res. J. Med. Plant. 5 (2011) 21-31, doi: https://doi.org/10.3923/ rjmp.2011.21.31.

20. F. Caili, T. Haijun, L. Quanhong, C. Tongyi, D. Wenjuan, UItrasound assisted extraction of xyloglucan from apple pomace, Ultrason. Sonochem. 13 (2006) 511-516, doi: https:// doi.org/10.1016/j.ultsonch.2005.09.007.

21. M. Vinatoru, An overview of the ultrasonically assisted extraction of bioactive principles from herbs, Ultrason. Sonochem. 8 (2001) 303-313, doi: https://doi.org/10.1016/ S1350-4177(01)00071-2.

22. H. Wang, X. Ma, Q. Cheng, X. Xi, L. Zhang, Deep Eutectic Solvent-Based Microwave-Assisted Extraction of Baicalin from Scutellaria baicalensis Georgi, J. Chem. 2018 (2018) 1-10, doi: https://doi.org/10.1155/2018/9579872.

23. S. Duraković, Uvod u opću mikrobiologiju, Kugler, Zagreb, 2002., str. 665.

24. M. R. Ramón, M. C. F. Espinoza, E. Durand, Application of Deep Eutectic Solvents (DES) for Phenolic Compounds Extraction: Overview, Challenges, and Opportunities, J. Agric. Food Chem. 65 (2017) 3591-3601, doi: https://doi. org/10.1021/acs.jafc.7b01054. 


\title{
SUMMARY
}

\section{Extraction and Stability of Olive Pomace Polyphenols in Natural Deep Eutectic Solvents}

\author{
Anamarija Mitar, Dajana Kučić Grgić, and Jasna Prlić Kardum*
}

Polyphenols, left in olive pomace, which is a by-product in the production of olive oil, are antioxidants that have a positive effect on human health. For the extraction of polyphenols, the use of natural deep eutectic solvents is increasingly encountered, characterised by non-toxicity, biodegradability, nonflammability, and low price. In this work, a natural deep eutectic solvent (NADES) was prepared from three components: malic acid, D-fructose, and glycerol (MaFruGly) with different water contents that allow successful extraction of polyphenols. The optimal extraction method was determined. Following extraction, the microbial activity was tested and stability of the isolated polyphenols monitored. Research has shown that the most successful methods for polyphenol extraction are microwave ultrasound and ultrasonic probe extraction, and NADES with $30 \%$ water has proven to be the optimal solvent for maintaining the stability of polyphenols.

\section{Keywords}

Extraction, polyphenols, natural deep eutectic solvents, stability of polyphenols

Faculty of Chemical Engineering and

Technology, University of Zagreb

Marulićev trg 19, 10000 Zagreb

Croatia
Original scientific paper Received August 28, 2019 Accepted September 18, 2019 